Article

\title{
The Right to Landscape: Social Sustainability and the Conservation of the State Theatre, Hong Kong
}

\author{
Leung Kwok Prudence Lau * and Pak Yin Ophios Chow \\ Department of Cultural and Creative Arts, The Education University of Hong Kong, Tai Po, Hong Kong, China \\ * Correspondence: plklau@eduhk.hk
}

Received: 5 June 2019; Accepted: 24 July 2019; Published: 25 July 2019

\begin{abstract}
This study analyses research gaps and identifies potential new research topics concerning the adoption of social sustainability values when conserving historic buildings, with a focus on the State Theatre (the Theatre) in Hong Kong. Despite becoming a Grade 1 historic building in March 2017, the Theatre has since faced an uphill battle, sustained only through public participation and widespread pressure on heritage authorities. In the process, problems with local heritage policy and the bureaucratic procedures of technocratic administrative bodies have been brought to light. Based on in-depth interviews with members of the local community, stakeholders, non-governmental organisations and heritage consultants, and using government policies and media reports, this study unveils and analyses issues related to the conservation of the Theatre using a humanised anthropological approach. The results highlight the need for a more socially sustainable future for cultural capital by integrating the notion of the cultural landscape with heritage conservation in Hong Kong.
\end{abstract}

Keywords: heritage conservation; social sustainability; cultural landscape; public participation

\section{Introduction}

It is not uncommon for historic buildings in Hong Kong to be threatened with demolition due to urban development. Since the adoption of the first heritage law, the Antiquities and Monuments Ordinance in 1976, which was designed to preserve historic, archaeological and paleontological sites or structures, the legal protection of historic buildings has been limited to those identified as 'monuments'. Also created under the 1976 Ordinance was the Antiquities Advisory Board (AAB), a statutory body of the Hong Kong government that evaluates local historic buildings and recommends that those with historical or architectural merit be listed as monuments. In addition to listed monuments, the remaining historic buildings in Hong Kong are categorised into three tiers, Grade 1, Grade 2 or Grade 3, which are not legally binding. Up to March 2019, 980 of the 1444 historic buildings assessed in Hong Kong were graded buildings [1]. However, as there is no statutory protection for these historic buildings, some 30 graded buildings have reportedly been demolished or substantially altered [2]. In AAB's Expert Panel for assessment of historic buildings in Hong Kong, only a selected few 'experts' were consulted before bestowing a grade upon each heritage. In the process, hard factors (such as the building age and architectural merits) often override human factors, including cultural value, social attachment, and identity. Urban heritage is inherited from past generations and some are even bonded to as "icons", being a projection from the human mind and spirit [3]. Without properly addressing local needs and attachment, the heritage cannot be sustainable and meaningful—they are just conserved as another salvaged building without souls. It is these human factors (cultural value, social attachment, identity, etc.) that contribute to the social sustainability of heritage conservation, and will form the conceptual framework throughout this article. 
Social sustainability, in fact, goes hand in hand with sustainable development. While former concepts of sustainable development involved architect-planners in designing 'green buildings' that stresses environmentally friendly designs and efficient energy use etc., recent concepts have rendered much broader and multi-disciplinary ideas that open to the views of others in decision making [4]. Rapoport moreover contends that socio-cultural factors shaped built forms and that environmental needs should support group culture, values, and needs [5]. Scholars have also proposed a 'Hong Kong model' of sustainable development and argue that "it can (and should) be articulated for the purpose of raising citizen awareness" [6]. Under the pressure of urban or real estate development, however, urban renewal in major cities is often sadly and purely interventionist, where a "perfunctory nod could be given to heritage conservation through the retention of a small part of the old building cluster" [7]. While this is often the case in Hong Kong as well as in major cities worldwide, recent studies have even shown that real estate development can, in fact, be mutually compatible with sustainable development [7] (p. 1). The authors of this paper, therefore, hope that recognised built heritage with redevelopment potential, like the case of the State Theatre, could not only be saved, but also revitalised, and functionally and socially integrated into a modern redevelopment with a lower impact on the existing heritage.

This study focuses on social value and to an extent spiritual value, which are often neglected in technocratic methods of heritage conservation in Hong Kong. It first demonstrates the role of social sustainability in heritage protection to identify the necessary involvement of the community and justify the act through the notion of the cultural landscape. Second, using on-site interviews with the local community, stakeholder dynamics are revealed (such as those of shop tenants, local residents and nongovernmental organisations (NGOs)), focusing on the recent controversy regarding Hong Kong's State Theatre (the Theatre) (built in 1952), which was essentially abandoned and later received historic building status (Grade 1). Third, the study applies the concept of the cultural landscape, which is still relatively new in Hong Kong, to the recent conservation controversy regarding the Theatre to demonstrate the link between local identity-making and social sustainability in a community. Even more importantly, it explains how social sustainability can be enhanced through heritage conservation and the creation of a sense of place. In some studies, this is referred to as the community-based cultural heritage resources management model [8], or community-based conservation for short, which shifts the core values from official to local. Finally, this study considers Hong Kong's cultural heritage as part of a larger landscape that constitutes the overall sustainability of the city.

\section{Foundation and Methodology}

\subsection{Heritage Conservation in Hong Kong: Early Beginnings}

A consultation document published in 2004, one of the government's first attempts to review the city's built heritage conservation policy, was ironically followed by the demolition of several landmarks, undermining the merit of public consultation and perceptions of the government's commitment to conservation [9]. The same year saw controversy over the King Yin Lei mansion, built in the 1930s, which nearly resulted in its demolition [10]. In the midst of the ongoing demolition work initiated by the owners of the historic mansion, the government intervened by proposing to list it as a monument in 2007, effectively declaring it as such in 2008. It was during these pivotal years that society experienced an increase in local conservation movements and public participation.

In 2006, public participation in heritage conservation was beginning to grow following two controversial incidents involving Star Ferry Pier and Queen's Pier, two British colonial-era ferry piers, the second of which had initially received Grade 1 status. Despite large-scale public protests and campaigns, Star Ferry Pier was destroyed and Queen's Pier was dismantled and due to be reassembled in a different location abutting the new waterfront following land reclamation. These examples highlight the problems of the heritage conservation mechanism and the grading system, particularly in the case of Queen's Pier, a modern utilitarian-style structure built in 1954 (the second generation of the 
pier constructed on the site) and dismantled in 2008 despite its Grade 1 listing, as this status was not legally binding for the government. Similarly, Star Ferry Pier, another modernist structure erected in 1957 (the third generation of this pier), was demolished as part of the land reclamation in early 2007 and replaced by a mock-Edwardian structure built to 'resemble' the former 1912 second-generation pier. Not surprisingly, this design was criticised and ridiculed by many as a fake replica of history or a 'Disneyfied' building resembling one in a theme park [11].

More recently, threats to demolish a street or an entire neighbourhood have empowered groups of local residents in Hong Kong to establish a 'community heritage discourse' [12]. This growing sense of belonging uses heritage to foster placemaking and a sense of community, essentially preserving the heritage and truly benefiting the neighbourhood. Therefore, making sense of place, heritage and landscape is not a static process but a plenum of accumulated sediments, knowledge and experiences, connecting the past, present and future.

\subsection{Social Sustainability in the Conservation of Cultural Heritage}

Sustainability has been a hot topic for years. It is essentially a means of 'developing and sustaining the quality of life' as a transdisciplinary approach to human well-being [13]. Nevertheless, the three main aspects of sustainability, economic, environmental and social, have been prioritised differently over time. The environmental aspect was the main concern in the 1960s, while the focus in the 1970s was on economic needs [14]. An overemphasis on economic viability and environmental protection in heritage led to an increase in social issues, including a loss of social continuity and problems of gentrification, threatening social cohesion and inclusiveness [15] (p. 397). Social sustainability is now another complicated concept that can be applied in heritage studies to address other aspects, such as quality of life, making sense of place, local identity and local public participation, particularly when planning and studying the role of heritage [15]. Nevertheless, the literature on the link between social sustainability and the historic built environment remains insufficient [16]. Social sustainability as a factor used to measure and evaluate a historic environment is very different from the more visible and quantifiable factors used in traditional methods, but it is equally worth adopting [17]. One of its advantages is the 'strong feelings of connection and identification with a community', enhancing individual participation and leading to social identity and cohesion [17] (p. 466). Moreover, 'social sustainability' in an urban context refers to 'the continuing ability of a city to function as a long term, the viable setting for human interaction, communication and cultural development' [18] (p. 140).

Whilst social sustainability is traditionally measured using quantitative factors, such as employment and income, Landorf suggests using new measures, including quality of life and social cohesion [17]. He even argues that governments in Europe and the United Kingdom should use social sustainability in public policies to promote greater social equality and social inclusion. In his article, Landorf examines a number of theories used to analyse social sustainability, including the capabilities approach $[17,19]$ and the sustainable development theory discussed at the United Nations Conference on Environment and Development $[17,20]$. The capabilities approach includes emotional development and control over one's environment, whilst the sustainable development theory is similar to public participation and identity-making [17] (p. 467). Social sustainability is not a simple issue, but it is an essential element of a healthy society. Landorf then identifies three dimensions: social equality, social cohesion and satisfaction of basic human needs [17,21]. Similarly, Yung and Chan [15] suggest four aspects of social sustainability that differ yet overlap with those proposed by Landorf: a sense of place and identity, quality of life, social inclusion and equality, and community access and participation. Although they do not use the same terminology, the two articles focus on similar factors and characteristics to measure social sustainability. Indeed, not only is the concept of social equality used in both studies, but Yung, Chan and Landorf refer to overlapping characteristics of social sustainability, albeit with different names $[15,17]$. To summarise the two articles, social sustainability is generally measured by the extent to which the landscape meets the following needs: (1) the basic needs of residents (quality of life); (2) the emotional needs of being in a community (social inclusion 
and identity-making) and (3) the right to participate in making sense of the landscape (community access and participation; Figure 1).

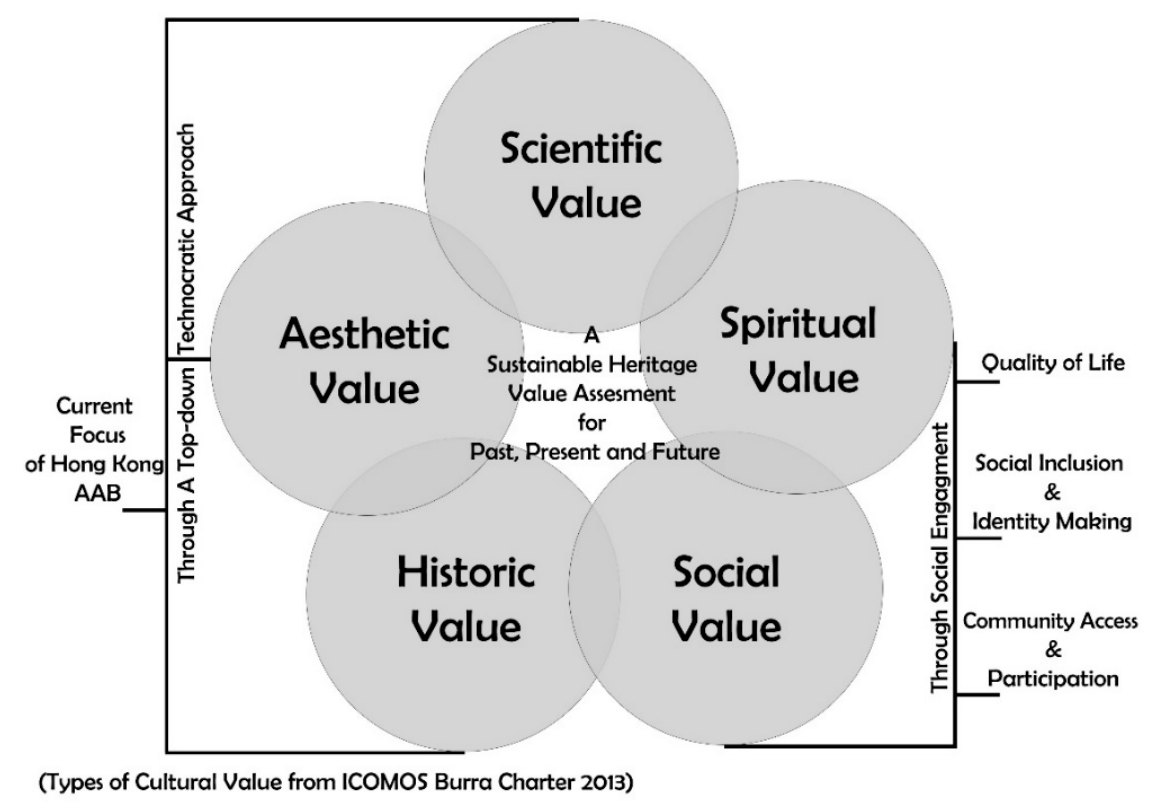

Figure 1. The five types of cultural value in the Burra Charter [22].

The above factors are, in fact, often intertwined and impossible to isolate. Quality of life is a concept recently discussed and used as an indicator of the well-being of people in a society [23]. It is measured by various factors, such as the standard of living, personal wealth and environment (e.g., noise, safety and cleanliness) [24], indicating the need to study our built environment. Previous research also suggests that the conservation of heritage buildings contributes to a higher degree of creativity, economic development, a better quality of life [15,25-27] and the 'social well-being' of communities [28]. This indicates that quality of life must be fulfilled both physically and mentally. Physical needs can be easily measured and met by external policies and improvements, but mental or emotional needs are more difficult to meet. Emotional needs include a sense of belonging to a community; for an individual, making sense of a collective identity to rationalise his/her position in this particular social group or 'imagined community' can lead to a better quality of life.

The commonly used ladder of citizen participation theory classifies public participation into three levels: the degree of citizen power, the degree of tokenism and nonparticipation [29]. Although this theory was developed in 1969 to study citizen participation at that time, it is still relevant today, particularly with regard to global inequalities and injustices. Arnstein concludes that citizen participation engages the 'have-nots' (who are not in power) in the policymaking process to truly benefit society with shared resources in the region [29] (p. 216). Nevertheless, she points out that some empty rituals of participation (or tokenism) only superficially claim that everyone benefits from them. In heritage conservation, the right to access and participate in the conservation process is important to satisfy the degree of citizen power. This satisfaction benefits the physical and mental needs of an individual and reinforces his/her identity. This relationship may seem complicated, but the above levels are all catalysts for improving social sustainability in a place and should be considered before economic and environmental factors. As a result, real citizen involvement and 'genuine participation' must take place in public policymaking to engender social sustainability.

\subsection{Methodology}

Whose heritage should be safeguarded is a common question in the field of conservation. Elite groups and technocrats are often seen as major players and stakeholders [30,31]. Our involvement in 
heritage protection can "change the nature of what it is that we deem to be significant and how we think, where the importance of a site is increased not by abstract values of rarity and condition but by the interactions of people drawn to study and explore it" [32] (p. 172). Although conceived in terms of archaeology, the above notion is equally applicable to urban heritage. Fieldwork is essential to understand the identity and space of a heritage site, as well as the role of emotion in geographies or landscapes [33] (p. 527). Anthropology and human experience are also key concepts adopted in this article. The research cannot be conducted without on-site interaction with people, as this not only produces mutual understanding and learning but also transform social knowledge, relations and forms of action onto another level by collaborative works between researchers and local actors [34]. To help us understand the complicated situation of heritage protection in Hong Kong, the authors conducted on-site fieldwork to observe and interview persons who are directly impacted by the conservation of the State Theatre. The interviews are qualitative and aimed at collecting local opinions in shaping landscape through emotion and local experience. Although only three interviews were conducted on the day of the field visit, these interviewees are the only survivors remaining in the Theatre arcade who are currently witnessing the final moments of the State Theatre. The attachment to a place depends on personal connection of the place and can never be fully understood without actual interaction, therefore, one comment from a local active player is greater than one from a distant expert. Although only a small sample, these three remaining participants are greatly justified to capture the views of the community, as they are the direct and active users of the heritage who also embody an attachment to the place. The authors also documented comments from archival research and newspaper clippings for further discussion on the captioned issue. The gap of valuation and attachments between locals and experts is then addressed for expressing the ongoing problems in heritage conservation in Hong Kong.

\section{The Social Perspective: A Panacea for Modern Heritage?}

As with the incidents of Star Ferry Pier and Queen's Pier, public participation has played a crucial role in the conservation of the Theatre, originally named the Empire Theatre when it opened in 1952. The Theatre was once Hong Kong's cultural hub, only eclipsed by the City Hall, a local art and cultural venue that opened 10 years later, in 1962. Located in North Point, Hong Kong Island, the Theatre was founded by Russian-Jewish impresario Harry Odell, a legendary giant in the history of entertainment in Hong Kong. In the post-war period, Odell started a film distribution company, Harry Oscar Odell's Commonwealth Enterprises Corporation Ltd., and arranged for internationally acclaimed artists to perform in Hong Kong and at the Theatre, including the late Taiwanese pop singer Teresa Teng, the late British tenor Peter Pears and Katherine Dunham's Broadway dance company [35]. The Theatre was also a popular venue for live shows, such as Chinese drama, opera and musical performances.

Architecturally, the building is unique. The roof of the auditorium is suspended from external parabolic concrete roof trusses, which are exposed to the public and are a prominent feature and trademark of the building. This ingenious design frees the auditorium of the need for pillars and allows for flexible internal arrangements. Designed by architects George W. Grey and S. F. Liu, the Theatre is adorned with a large decorative relief created by the renowned Lingnan artist Mui Yu-tin, featuring the ancient Chinese tale of 'The imperial warlord Dong Zhuo and the legendary beauty Diao Chan'. With framed square architraves and banded windows harmoniously fronting the elevation of the Theatre, the entire building has a distinct modernist and art deco quality (Figure 2). In 1959, it was renamed 'State Theatre' and, perhaps for practical reasons, the building was converted into a theatre-cum-shopping complex, and a multi-storey block with shops, residential apartments and a night club was opened on the adjacent site. The Theatre eventually ceased operations in 1997 and is now a billiard centre with removable partitions sealing the upper deck of the auditorium. The rest of the complex currently consists of a run-down shopping arcade on the ground floor that will cease operations by the end of 2019 and small residential apartments that are largely vacant. 


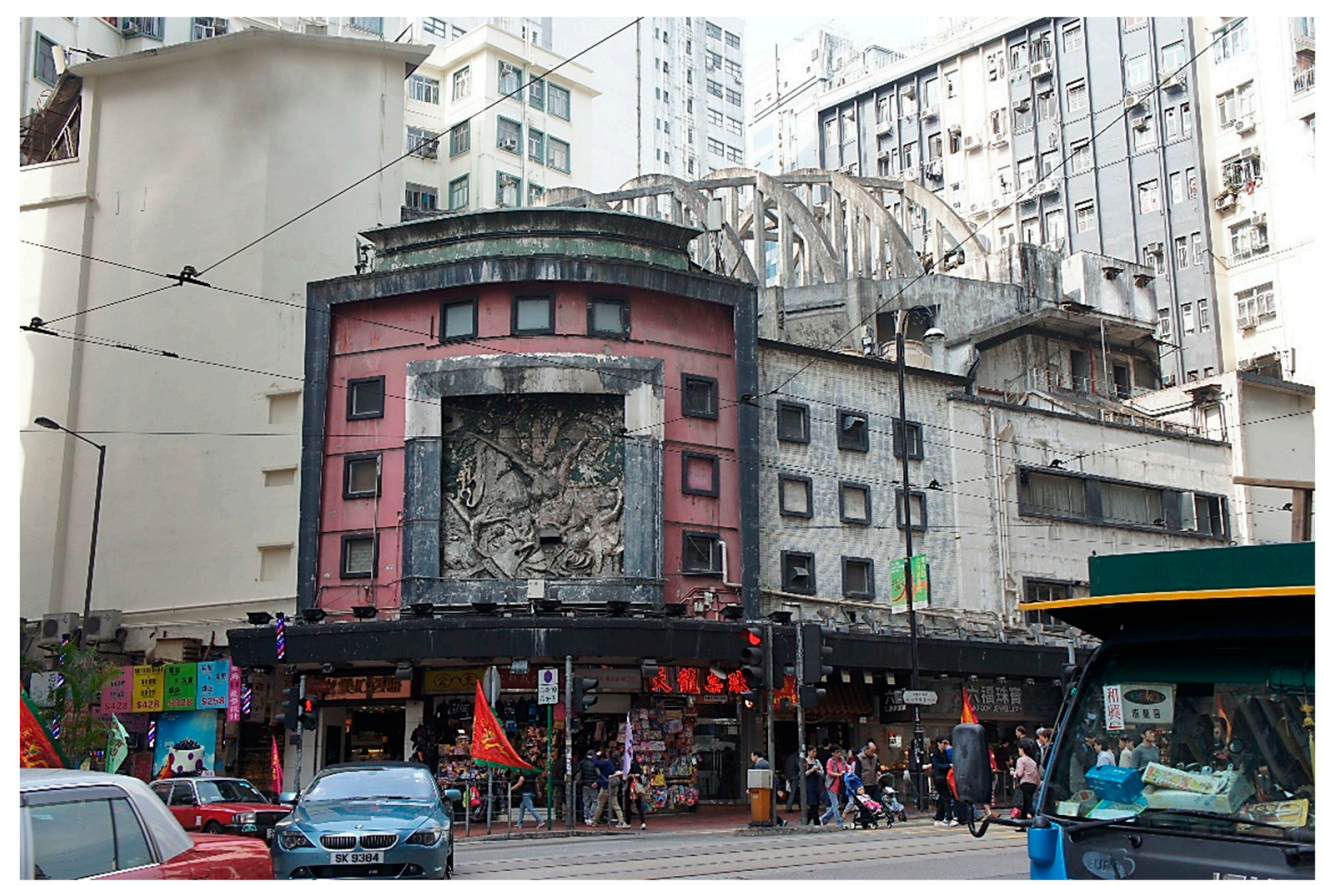

Figure 2. The State Theatre in January 2019, with the shopping arcade located on the ground floor. (photograph by Lau, L.K.P.).

Following the proposal for Grade 3 status (see Table 1) issued by the Antiquities and Monuments Office (AMO) in April 2016, a televised programme about the incident aired by Radio Television Hong Kong (RTHK) in late May revealed that some of the panel members ranked buildings by age, dismissing their social and cultural value. Commenting on the Theatre, one of the members, an architect, stated, 'Personally, I do not pay much attention to the reference materials [building appraisals prepared by the AMO]'. Then, referring to the unique design of the parabolic roof trusses, he commented that 'everything can be unique, but the structure of the State Theatre is in fact very ordinary' [36]. Such inherent tensions between form and function in modern heritage are not something new-challenges in the preservation of modern architecture is gaining academic attention in the recent decade or so $[37,38]$. Particularly, Mualam and Sybblis [39] analysed the obstacles and standards to balance form and function in modern heritage, and suggest that such a process should go beyond scientific innovation or professional opinion. Focusing their study on the preservation of a concert hall in Tel Aviv (built 1957), they propose that final decisions in conserving modern architecture should, in fact, rely on "the professionals and locals who occupy the public heritage venues and whose activity is intricately tied with the functional existence of the historic site" [39] (p. 146). Mualam also conducted similar studies that highlight the importance of social aspects in recent heritage protection work, indicating the growing role of social considerations in built-heritage policies [40].

Table 1. Major chronological events in the State Theatre incident.

\begin{tabular}{cc}
\hline Year & Event \\
\hline 11 December 1952 & Opening of the Empire Theatre 璇宮戲院 (original name of the State Theatre) \\
\hline 1957 & Closed for business \\
\hline 1959 & Reopens as the State Theatre 皇都戲院 \\
\hline
\end{tabular}


Table 1. Cont.

\begin{tabular}{|c|c|}
\hline Year & Event \\
\hline 28 February 1997 & $\begin{array}{c}\text { Official closure of the Theatre } \\
\text { (other shops in the complex remain open for business) }\end{array}$ \\
\hline July 2015 & Start of acquisition by New World Development Limited \\
\hline 23 March 2016 & $\begin{array}{l}\text { Walk in Hong Kong (WIHK), a local NGO and heritage group, writes to } \\
\text { Docomomo International for an expert opinion on the State Theatre's eligibility } \\
\text { to be listed on the 'Heritage in Danger' alert list. Prof. Jos Tomlow, a member of } \\
\text { the Docomomo International Specialist Committee on Technology, immediately } \\
\text { writes a report praising the Theatre's architectural expression and rarity }\end{array}$ \\
\hline April 2016 & $\begin{array}{l}\text { WIHK and researchers from the Chinese University of Hong Kong publishes a } \\
\text { Heritage Value Assessment [41] }\end{array}$ \\
\hline April 2016 & $\begin{array}{l}\text { Televised interview reveals controversial comments } \\
\text { from the expert panel on the State Theatre }\end{array}$ \\
\hline 15 April 2016 & $\begin{array}{l}\text { The Antiquities Monuments Office proposes a Grade } 3 \text { status } \\
\text { for the State Theatre }\end{array}$ \\
\hline 15 April 2016 & $\begin{array}{l}\text { Joint Statement to the Antiquities Advisory Board (AAB) by WIHK, the } \\
\text { Conservancy Association (another local NGO) and Docomomo Hong Kong }\end{array}$ \\
\hline 18 April 2016 & $\begin{array}{l}\text { The heritage rating decision on the State Theatre was postponed after an } \\
\text { inconclusive meeting by the AAB }\end{array}$ \\
\hline 8 September 2016 & $\begin{array}{l}\text { WIHK and Wendy Ng prepares an 'information pack' on the State Theatre and } \\
\text { distributed it to AAB members prior to their meeting }\end{array}$ \\
\hline 8 September 2016 & The AAB proposes a Grade 2 status for the State Theatre after their meeting \\
\hline 7 December 2016 & $\begin{array}{l}\text { The Heritage Committee of the Hong Kong Institute of Architects (HKIA) } \\
\text { issues a letter to the AAB asking for accurate classification of the State Theatre }\end{array}$ \\
\hline 8 December 2016 & $\begin{array}{l}\text { WIHK and Wendy Ng update their 'information pack' to include the public's } \\
\text { latest news, memories and comments regarding the State Theatre and submit it } \\
\text { to the AAB prior to their meeting }\end{array}$ \\
\hline 8 December 2016 & $\begin{array}{l}\text { The AAB grants Grade } 1 \text { status, marking the start of } \\
\text { a one-month public consultation period }\end{array}$ \\
\hline 9 March 2017 & The AAB confirms the Grade 1 status of the State Theatre \\
\hline 22 October 2018 & $\begin{array}{l}\text { New World Development, a local property developer, applies for a compulsory } \\
\text { sale order for the State Theatre Building but did not reveal the details of the } \\
\text { redevelopment plan, leaving the future of the State Theatre uncertain }\end{array}$ \\
\hline
\end{tabular}

Modern heritage has also been referred to as 'icons', and its 'bond' with people gives them reassurance, while it in turn "reinforces our sense of order in the world no less than religion or popular culture" [3] (p. 46). According to Costonis' classic book on Icons and Aliens: Law, Aesthetics, and Environmental Change, icons come in all shapes and sizes and find support among diverse groups of people. They are also "a projection of the human mind and spirit, loved when they live and mourned when they die [3] (p. 48)". However, Costonis argues that the value of icons does not always rely on its formal 'aesthetic' qualities, but sometimes on its contribution to our sense of "identity and stability" [3] (p. 66) over time. He takes Chicago's Water Tower as an example, indicating that it is considered an icon not because of its architectural qualities, but because it survived the city's Great Fire of 1871. It is the importance of the social perspectives, attachment or bond that this study seeks to argue for in the case of Hong Kong, to explain the seemingly rare success story of the ongoing preservation of the State Theatre. 


\section{Findings}

In light of recent studies that take into account the social aspects of heritage protection, the authors of this study collected the views of local participants and community stakeholders associated with the placemaking process, and who are also directly or largely affected by the decisions of policymakers regarding the State Theatre in Hong Kong.

\subsection{Local Shop Tenants}

The group most directly affected should be the shop tenants who still operate inside or have just left the Theatre. To obtain the latest and most relevant data for our case study, these tenants were interviewed in January 2019.

Mr Wen, tenant of a shoe shop known as 美高梅 (pronounced Mei-Go-Mui) has been operating in the Theatre for over 7 years. The rent is about HK $\$ 15,000$ per month for his shop of about 300 square feet. Before the Theatre closed, he remembered that there were five or six shoe shops in this shopping arcade (there are only two left, including his shop). As there was a large number of Fujianese residing in the North Point area, business was good in the past and peaked particularly during the Chinese New Year, when it was common practice to purchase daily goods as gifts for relatives in mainland China. When asked if he would stay at the State Theatre shopping arcade if given the choice, he said a definite yes. He explained that even though business was nothing like the good old days, he was still earning a steady income and the network of kaifong (according to Hong Kong government reports, "kaifong" is a Cantonese expression meaning the residents of a particular street or locality [42] (p. 65)) he had accumulated after many years would disappear if he left. As the authors witnessed, he enjoyed his daily conversations with passers-by, even if they left without making a purchase.

Our second interviewee, Mr Tsang, was one of the brothers owning a tailor shop business known as 輝煌洋服 (pronounced Fai-Wong-Yeung-Fuk) in the arcade, a beacon in the currently dark alleyways. He explained that he was, in fact, a kaifong and originally resided in North Point. The brothers opened a shop here in the 1980s after renting their own shop in North Point. Their rent is around HK\$8000 per month for a shop of about 200 square feet. A similar shop would cost them about HK\$60,000 per month, which is almost 10 times their current rent at the Theatre arcade. Mr Tsang also expressed the desire to stay there for the following reasons: (1) the kaifong, (2) sentimental feelings and (3) he was able to maintain a reasonable business or income.

We were also able to approach a former shop tenant whose late father had worked as a Chinese medicine practitioner in the Theatre arcade from 1991 to 2017. Like most shops in the Theatre arcade, the original store (opposite Mr Tsang's tailor shop) is currently closed, and a sign on the closed shutters indicates its new location. The authors interviewed $\mathrm{Ms} \mathrm{Fu}$, the daughter of the late Chinese medicine practitioner, in her new shop on the ground floor of Coronet Court. This new location, also along King's Road, is only a stone's throw from the Theatre building, reflecting Ms Fu's desire to stay within walking distance of her original network of clients or patients. She lamented that her current location was nothing compared with the close-knit community of shop tenants at the State Theatre, which she explained was 'as busy as a village' (interview with the authors, 17 January 2019) and where everyone knew and watched out for each another. The rent was also much cheaper at the Theatre, where a 200-square-foot shop in 2017 cost only about HK\$7000, compared with HK\$15,000 a month for her current 130-square-foot shop. She admitted that she would have preferred to stay in the Theatre arcade and only left because her lease had expired.

Indeed, all three interviewees pointed out that the rent at the Theatre was much cheaper than their current rent in the rest of the North Point area. Although no details of the State Theatre's redevelopment plans have been disclosed, it is rare for original tenants to be able to return to the original building after the heritage conservation process in Hong Kong. Lee Tung Street in Wan Chai (currently renamed 'Lee Tung Avenue') is a perfect example. Previous shop owners, mainly engaged in printing traditional Chinese wedding invitation cards, criticised the Urban Renewal Authority for reneging on its promise to allow indigenous shops to reopen and enjoy preferential rent along the historic street, instead 
accommodating luxury retail stores [43]. The public and the local community are well aware of this harsh reality. In fact, when we left Mr Wen's shoe shop, we overheard a passer-by explaining to his daughter about the imminent redevelopment of the State Theatre. He told her that 'even when these tenants return, it will not be the same' [搬返入去唔系呢一回事].

\subsection{Local Concern Groups and Individuals}

In addition to the shop tenants who will be or have been affected by the looming redevelopment of the Theatre, those who are emotionally attached to the Theatre, such as customers, past kaifong and local concern groups, should be considered as active stakeholders of the heritage.

One such example is Ms Wendy $\mathrm{Ng}$, a local heritage consultant whose mother opened a shoe shop in the shopping complex of the Theatre that operated from 1984 to 1997. The shop's name, Wan Yee Company (韻怡公司), was based on Ms Ng's first name in Chinese, indicating and revealing her personal attachment to the building. Ms $\mathrm{Ng}$, who is also a local heritage consultant, played a key role in the conservation of the Theatre by collaborating with an NGO, Walk in Hong Kong (WIHK), to help compile an 'information pack', which was presented to the Antiquities Advisory Board before it debated and decided on the grading of the building. In an interview with the first author, reflecting on the Theatre's conservation journey, she felt that the community groups in Hong Kong were passionate about heritage conservation, but they did not know where to start or what steps to take (interview with the first author, 13 December 2016). Moreover, she admitted that the temporary success of the Theatre's upgrade to Grade 1 was largely due to the media attention and public participation it garnered.

Paul Chan, co-founder of the local cultural heritage group and the NGO, WIHK, led the campaign to save the Theatre. He explained that they had adopted a different approach to advocacy work from that of 'traditional' NGOs in the past. Instead of organising public protests or hunger strikes, they took advantage of modern technology and social media to spread the word and raise awareness among the general public. In an interview with the author, he recalled the various media-oriented strategies they had used in the hope of 'getting everyone involved' (e.g., 'Roadshow' videos on public transport, interviews with renowned directors and actors who had filmed at the State Theatre, online petition, social media posts and invitations for comments and artistic sketches of the Theatre; interview with the first author, 28 March 2017). All of the information and resources gathered online were then compiled into an 'information pack' [44], which was distributed to the members of the Antiquities Advisory Board prior to their meeting regarding the heritage rating of the State Theatre (Table 1). His team also organised numerous public field trips to the Theatre, providing docents and on-site interpretation and visual aids, to enable the public to 'build [an] emotional attachment' to the building (interview with the first author, 28 March 2017). As indicated by the chronological events in Table 1, the WIHK also partnered with other independent public bodies to carry out successive advocacy actions for the Theatre, as a form of 'public consultation', which the authorities did not carry out for the building. In the end, the public's efforts and feelings about the Theatre had a considerable effect on the AAB's final decision in March 2017 to upgrade the building's historic status to Grade 1.

\section{Discussion}

\subsection{Cultural Landscape and Heritage Conservation in Hong Kong}

As evidenced by the State Theatre incident, the cultural landscape plays an essential role in growing local feelings about heritage conservation. Contrary to UNESCO's definition of heritage, which refers to the 'legacy of physical artefacts and intangible attributes of a group or society that are inherited from past generations, maintained in the present and bestowed for the benefit of future generations' [45], study of the cultural landscape is now closer to an ontological study of human experiences entangled with physical evidence. In Wattchow's classification of the 'trans-disciplinary concepts' of landscape, he identifies various subdisciplines, including landscape archaeology, landscape architecture, landscape ecology and landscape planning [46]. As we argue in this study, public participation is essential to 
access the true value of heritage and thus enhance social cohesion and social sustainability. However, this study also identifies the weaknesses of public participation mechanisms in Hong Kong that leave little room for local voices. This is similar to Smith's notion of Authorized Heritage Discourse, which explains the problems posed by a top-down management approach to heritage conservation [30]. It is clear that the situation in Hong Kong aligns with these criticisms, hindering the development of social sustainability in local conservation processes.

\subsection{Cultural Landscape of the State Theatre}

In July 2015, a local property developer, New World Development Company Limited, purchased several apartments in the Theatre complex, and rumours of demolition and redevelopment of the site started to spread. In April 2016, the Antiquities and Monuments Office- the government body responsible for assessing and proposing grades for historic buildings before submitting them to the $\mathrm{AAB}$ - recommended giving the Theatre a Grade 3 status, the lowest classification in the local grading system for historic buildings. However, no official grade was given to the Theatre, as the local heritage policy focuses on buildings constructed before 1950. Since 1996, the AMO has surveyed approximately 8800 buildings around Hong Kong and selected 1444 buildings with high heritage value to conduct a more in-depth survey before giving each of them a proposed grading. These buildings and their respective proposed grading were assessed according to six criteria: historical interest, architectural merit, group value, social value, local interest and authenticity and rarity. In March 2005, an expert panel composed of local historians and members of the Hong Kong Institute of Architects, the Hong Kong Institute of Planners and the Hong Kong Institution of Engineers was formed by the AAB to conduct an in-depth assessment of the heritage value of these buildings, based on a 'scoring exercise' on building appraisals drafted by the AMO [47].

In the Theatre incident, the heart of the problem was the composition of the expert panel, and to a certain extent, the subjective opinions of its members on historic buildings. In the same televised RTHK interview in May 2016, another member of the expert panel, this time a historian, challenged the value of the State Theatre. He commented that 'the Theatre only affects the neighbourhood of North Point (located on Hong Kong island) and not Kowloon or the New Territories (the rest of Hong Kong). Therefore, the State Theatre has only a local district value and not a social value. Moreover, how many people [still] watch movies in Hong Kong?' (Original transcription: 「舊皇都只影響北角, 香港九龍新 界呢? 那只是地區價值, 不是社會價值。而且全港有多少人看電影?」) This particular panel member, a professor in a local university, is renowned for his work on ancient Chinese history. However, many found his next statement difficult to justify and biased against modern architecture or cultural heritage: 'If the tombs of the Han Dynasty are worth five points, the Qing Dynasty [architecture] is worth at most four points. How many points then is the State Theatre worth?' [36] (Original transcription: 「漢 墓值 5 分, 清代(建築) 最多 4 分, 咁皇都幾多分?」)

When the above interview aired and was shared on social media, the video went viral and was followed by huge criticism and heated debate in local society. Many questioned the objectivity of the members of the expert panel given their significant influence on the fate of historic buildings in Hong Kong. Criticising the 'top-down' approach to heritage conservation in Hong Kong (interview with the first author, 28 March 2017), WIHK members decided to challenge the lack of transparency and the bureaucratic system of the Antiquities and Monuments Office at the beginning of their State Theatre campaign. Paul Chan of the WIHK recalled that they 'sought their own experts' to comment on the building and wrote to Docomomo International in March 2017 to include the Theatre on their 'Heritage in Danger' list. Docomomo International, short for the International Committee for Documentation and Conservation of Buildings, Sites and Neighbourhoods of the Modern Movement, is considered a 'key body for the preservation of modernist architecture' [48] (p. 324). A member of the Docomomo International Specialist Committee on Technology was approached to give his opinion on the State Theatre. This specialist, a professor from the University of Applied Sciences in Germany, wrote a report on the Theatre, recommending that it be 'considered as a piece of commercial architecture with 
high regards for functional aspects and at least partly an excellent piece of concrete construction both in architectural expression, structural logic and material execution' [49] (p. 1). The report further analysed other architectural aspects of the Theatre and concluded that 'this small and unique building complex, not only in respect to Hong Kong but to the World Heritage, as an excellent monument, needed to get the highest possible care for its preservation' [49] (p. 3).

The striking contrast between the comments of the members of the local expert panel and those of an architectural specialist from an overseas non-governmental organisation for heritage preservation further highlights the problems of entrusting the fate of Hong Kong's historic buildings in such a technocratic manner. Given the above justification of the Theatre's functional and architectural value by a foreign specialist, one cannot help questioning the validity of the comments made by the members of the local expert panel and whether other graded buildings in Hong Kong were assessed fairly and objectively. It is thanks to this incident that the problems of the top-down technocratic heritage assessment mechanism in Hong Kong have been brought to light, revealing major flaws in the local heritage conservation policy for historic buildings, in which social significance or issues are often dismissed or even neglected.

To improve this mechanism, other theories and factors should be incorporated into the formulation of a heritage assessment report instead of focusing solely on historical or physical aspects to truly measure the value of heritage in a community. The cultural landscape should be one of the factors or methods used to decode public opinion and the underlying social value of heritage. From the perspective of the cultural landscape, a heritage asset should not be viewed as a static object but as a manifestation of invisible and emotional factors that define a community in terms of landscape, streetscape or buildings. Personal thoughts and feelings, such as memories or a sense of belonging, are often attached to physical remains and thus should not be discussed separately. In the case of the Theatre, judging only its architectural merit would be unfair and unsustainable for the public, as the palimpsest of complicated layers would be erased by rational scientific judgment or Authorized Heritage Discourses, as proposed by Smith [30]. Although some heritage experts (as seen above) claim that the building is worthless or ordinary because of its date of construction, the question is whether they truly understand the meaning of the building for its community. Others may then estimate how 'sustainable' it is to knock down the old structure and create a new mega-structure in monetary terms. What they seem to have forgotten is that sustainability cannot only rely on economic advancement but must also take into account social and environmental aspects. When functionalism drives heritage conservation, we turn cultural capital into pure capital, in this case, the capital of the developer and not that of the community. By conserving heritage, we create room for further opportunities to sustain the neighbourhood and, in this case, the identity of the North Point area. The Theatre is not a private place serving an individual, but a place of social interaction in the neighbourhood. This is how the cultural heritage landscape really works, not through recent governmental schemes, such as the outdated 'point-line-plane' approach [50].

\subsection{The Right to Landscape}

As stated by a former member of the expert panel (who had served until 2007; the panel currently consists of five members [51]), the success of Hong Kong's long-term development lies not only in its physical, economic and technological aspects, but also in the 'underlying cultural heritage assets that will give Hong Kong its soul and identity' [52]. Furthermore, as emphasised in the Burra Charter, heritage conservation cannot be sustained without community participation [22] (Article 12). In his 2007-2008 Policy Address, the Chief Executive of Hong Kong proposed a series of initiatives, including the creation of the position of Commissioner for Heritage in the Development Bureau as a 'focal point for public participation' and conservation [53].

As Egoz, Makhzoumi and Pungetti state, everyone has the 'right to landscape', and this landscape provides us with the necessities of life and the proof of our belonging and existence [54] (p. 329). In contrast, Schama claims that memories shape the landscape and in return, the landscape shapes 
memories [55] (p. 7). This is created and reinforced by the continuous input of the community, as a 'mental and social construct with important symbolic meaning' according to Antrop and Eetvelde [56] (p. 21). However, as evidenced by the above incidents, heritage conservation in Hong Kong has unfortunately been dominated by bureaucratic authorities or technocrats, and public participation has often been dismissed or considered insignificant in policymaking. Moreover, as shown in previous studies, these technocrats or experts often disparage the public's role in determining or understanding the value in heritage conservation [57] (p. 461). Meinig published an important book on the landscape in 1979 when the topic was still tackled from a scientific perspective. In the chapter 'The Beholding Eye: Ten Versions of the Same Scene', he argues that 'even though we gather together and look in the same direction at the same instant, we will not—we cannot—see the same landscape' [58]. As Meinig suggests, each viewer has his/her own unique pair of lenses and it is impossible for everyone to see the same picture even when looking at the same scene. Therefore, why should a particular opinion or perspective be more important than others?

In Hong Kong, tokenism in public participation also affects the public's willingness to participate in heritage conservation. As explained by Arnstein's ladder of citizen participation mentioned earlier, this occurs when the public feels involved only at a superficial level of consultation and unable to influence the outcome or change the status quo [29] (p. 217). Due to non-transparent and undemocratic decision-making systems that lead to the failure of heritage conservation, the role of local interest groups or community organisations (e.g., WIHK) has increased. In addition, the mobilisation of interest groups has become the main way for 'have-nots' to express their opinions [57] (p. 465). Moreover, community participation in heritage conservation can positively affect the sense of belonging, enhancing local pride, sense of community and quality of life [59] (p. 6). This sense of belonging and sense of identity have particularly intensified since the incidents of Star Ferry Pier, Queen's Pier and now the Theatre, all of which have fundamentally challenged and triggered feelings about one's past and heritage [60]. In the on-site research conducted by the authors, the shop tenants clearly showed a deep connection to the local community and even to customers beyond this district, allowing them to control their own landscape and living conditions. This has also created an economic environment suitable for that particular community that has lasted for almost 30 years. A sudden termination of activities affects not only shop tenants, but also people who regularly visit them for goods and services, or even just for daily conversations. This modifies the economic landscape and leads to gentrification in the local community, but also changes the social cohesion and structure of the place. After redevelopment, the local community may not be able to adapt to the new economic mode. Therefore, the local economic system may suddenly collapse and be forcibly replaced by new companies that are foreign to the region, accelerating the loss of local survivors. When conserving a heritage or even a landscape, social dynamics must be considered and economic benefits should be given a less important role, at least during the early stages, in the interest of social well-being and less destructive effect on the community.

\section{Conclusions}

It is time for Hong Kong to adopt a new concept for evaluating and conserving heritage and landscape, at least for government bodies and professionals. This study contends that the concept of the cultural landscape should be used to discuss indicators of the social value of historic buildings for the community. Making sense of place goes hand in hand with the interaction between the community and individuals in the process of landscape creation. The hardware or building alone is nothing without the proper acknowledgement and inclusion of past and remaining stakeholders. Meeting the needs for (1) quality of life, (2) social inclusion and identity-making and (3) community access and participation ultimately allow the landscape and community to be culturally and emotionally sustainable. With a well-planned economy and environment in the area, these are the three dimensions of a sustainability model.

This study concludes that 'true' sustainability is a relative concept that is adaptive and should respond to its respective community. Sustainability in heritage conservation should be determined 
not only by financial gain but also by the cohesion generated through the use of the space, clearly illustrated in the dynamics between shop tenants and customers of the Theatre. The economic income that can finance the heritage building is 'sustainable' from a macroeconomic perspective, but whether this generated income can contribute to social cohesion and identity-making in the community is another story. Applying social sustainability to heritage conservation is, therefore, more appropriate and effective to Hong Kong's current situation in urban (re-)development. It is highly recommended that the mechanism of heritage grading or evaluation exercise be improved in Hong Kong, in order to address the needs of local communities and their rights to the landscape. Nevertheless, the intention here is not enduing local communities the power to override any decision made by the AAB or the government; this 'right' should, in fact, respect the opinions and consultation with experts in the field. In order to achieve a fair assessment for heritage buildings, the so-called 'expert panel' should be expanded to include more professionals and local participants who represent and understand social values of the heritage, who should study how current users would be affected for the sake of the "right to the landscape". This 'right' could moreover serve as a form of regulation of the expert panel and $\mathrm{AAB}^{\prime} \mathrm{s}$ decisions. It will certainly require time to formulate a comprehensive plan to negotiate where to draw the boundary of this 'right' in Hong Kong, but the social responsibility for decision-makers to involve and accept more public voice is inevitable.

The Theatre, narrowly escaping demolition and 'rescued' by consolidation of public efforts, is only the third building built after 1950 to be listed as a Grade 1 historic building in Hong Kong. As mentioned earlier, Queen's Pier (built 1954), also a Grade 1 building, is already destroyed. These incidents raise questions about the problematic heritage policy in Hong Kong and the objectivity of a small group of experts who are directly related to the fate of heritage buildings. Despite being set in Hong Kong, the State Theatre case is useful for local governments and preservation bodies elsewhere around the world, where similar debates of form and function would certainly be evident in modern heritage buildings. The analysis here focuses on whether modern public buildings, being a theatre in Hong Kong or a concert hall in Tel Aviv, can be preserved and adapted to fit modern-day needs, including the needs of the community as well as urban development. The balance between these two realms, as well as the values attached to cultural and heritage 'icons' need to be sought. There is indeed no single answer to the preservation of these modern structures, but seeking equilibrium between interests, preservation and development appear to be the way forward.

More than two years have passed since the Theatre received its Grade 1 status. On the positive side, recent reports indicate that the developer who acquired the majority of the properties of the Theatre complex is 'considering a conservation project for the first time' on this site [61]. With the redevelopment plan still in its infancy, a spokesman from the developer company shared the company's 'view to conserve [the] relevant part of the building' [61]. In light of this relatively positive state, the role of public participation in advocacy for the conservation of the Theatre cannot be understated. Previous public campaigns in local heritage conservation involved prolonged and tiresome public protests, hunger strikes and sometimes physical conflicts with law enforcement authorities, often without results. Therefore, ingenious new strategies using and engaging online platforms, social media and Web-based petitions, as evidenced by the work of non-governmental organisations and the voluntary sector discussed in this study, can effectively mobilise public efforts and move beyond exclusive boundaries by creating a truly community-generated process of heritage conservation. At the time of writing, only a handful of shop tenants, including Mr Wen and Mr Tsang, remain in the State Theatre for business, counting down the days until the end of their lease, marking the end of their time in the building. Their future remains bleak, both suggesting that it would be impossible to continue their business in another location in the district. When the day comes, it will signal the disappearance and dissolution of an entire local network and community. What about the future of the redevelopment of the State Theatre and its broader cultural landscape? Within the local community, from past and future cinemagoers to shop tenants in the Theatre, the general hope is that the show will go on. 
Author Contributions: Conceptualization, L.K.P.L.; methodology, L.K.P.L. and P.Y.O.C.; formal analysis, L.K.P.L. and P.Y.O.C.; investigation, L.K.P.L. and P.Y.O.C.; resources, L.K.P.L. and P.Y.O.C.; data curation, L.K.P.L. and P.Y.O.C.; writing-original draft preparation, L.K.P.L.; writing-review and editing, L.K.P.L. and P.Y.O.C.; visualization, L.K.P.L.; supervision, L.K.P.L.; project administration, L.K.P.L.; funding acquisition, L.K.P.L.

Funding: This research was funded by The Education University of Hong Kong Teaching Development Grant, grant number T0211.

Acknowledgments: The authors are grateful to the 3 anonymous reviewers and academic editor for their comments and suggestions for improvement.

Conflicts of Interest: The authors declare no conflict of interest. The funders had no role in the design of the study; in the collection, analyses, or interpretation of data; in the writing of the manuscript, or in the decision to publish the results.

\section{References}

1. Antiquities Advisory Board. 1444 Historic Buildings and New Items in Addition to 1444 Historic Buildings-Results of the Assessment of 1444 Historic Buildings. Available online: http://www.aab. gov.hk/en/aab.php (accessed on 6 June 2019).

2. Hong Kong Needs Review of Historic Building Heritage Policy. Available online: https://www.scmp. com/comment/insight-opinion/article/1204256/hong-kong-needs-review-historic-building-heritage-policy (accessed on 1 March 2019).

3. Costonis, J. Icons and Aliens: Law, Aesthetics, and Environmental Change; University of Illinois: Urbana/Chicago, IL, USA, 1989.

4. Kohler, N. The relevance of green building challenge: An observer's perspective. Build. Res. Inf. 1997, 27, 309-320. [CrossRef]

5. Rapoport, A. Human Aspects of Urban Form: Towards a Man-Environment Approach to Urban Form and Design; Pergamon Press: Oxford, UK, 1977.

6. Lai, L.W.C.; Chau, K.W.; Ho, D.C.W.; Lorne, F.T. A “Hong Kong” model of sustainable development. Prop. Manag. 2016, 24, 251-271.

7. Lai, W.C.L.; Lorne, F. Sustainable urban renewal and built heritage conservation in a global real estate revolution. Sustainability 2019, 11, 850. [CrossRef]

8. Keitumetse, S.O. Cultural Resources as Sustainability Enablers: Towards a Community-based Cultural Heritage Resources Management (COBACHREM) Model. Sustainability 2014, 6, 70-85. [CrossRef]

9. Public Affairs Committee; Hong Kong Institute of Planners. Review of Built Heritage Conservation Policy Consultation Document. Available online: https:/www.hkip.org.hk/en-position-papers/2017/10/29/reviewof-built-heritage-conservation-policy-march-2004 (accessed on 8 November 2018).

10. Frew McMillan, A. The King Yin Lei Mansion in Hong Kong Is Saved. Available online: https://www.nytimes. com/2011/05/01/travel/01headsup-hong-kong.html (accessed on 7 October 2018).

11. Tze-Wei, N. Not Even HK's Storied Star Ferry Can Face Down Developers. Asia-Pacific-International Herald Tribune. Available online: https://www.nytimes.com/2006/11/10/world/asia/10iht-ferry.3482674.html? _r=0 (accessed on 7 October 2018).

12. Lu, T. Empowerment, Transformation and the Construction of 'Urban Heritage' in Post-colonial Hong Kong. Int. J. Herit. Stud. 2016, 22, 325-335. [CrossRef]

13. De Vries, B.J.M.; Petersen, A.C. Conceptualizing Sustainable Development: An Assessment Methodology Connecting Values, Knowledge, Worldviews and Scenarios. Ecol. Econ. 2009, 68, 1006-1019. [CrossRef]

14. Colantonio, A. Social Sustainability: A Review and Critique of Traditional Versus Emerging Themes and Assessment Methods. In Sue-Mot Conference 2009: Second International Conference on Whole Life Urban Sustainability and Its Assessment: Conference Proceedings, Loughborough, UK, 22-24 April 2009; Horner, M., Price, A., Bebbington, J., Emmanuel, R., Eds.; Loughborough University: Loughborough, UK, 2009; pp. 865-885.

15. Yung, E.H.K.; Chan, E.H.W. Critical Social Sustainability Factors in Urban Conservation: The Case of the Central Police Station Compound in Hong Kong. Facilities 2012, 30, 396-416. [CrossRef]

16. Stubbs, M. Heritage-sustainability: Developing a Methodology for the Sustainable Appraisal of the Historic Environment. Plan. Pract. Res. 2004, 19, 285-305. [CrossRef] 
17. Landorf, C. Evaluating Social Sustainability in Historic Urban Environments. Int. J. Herit. Stud. 2011, 17, 463-477. [CrossRef]

18. Yiftachel, O.; Hedgcock, D. Urban Social Sustainability: The Planning of an Australian City. Cities 1993, 10, 139-157. [CrossRef]

19. Sen, A. Commodities and Capabilities; North-Holland: Amsterdam, The Netherlands, 1985; ISBN 978-0195650389.

20. UNESCO. United Nations Sustainable Development, Agenda 21. Available online: https:// sustainabledevelopment.un.org/content/documents/Agenda21.pdf (accessed on 7 May 2018).

21. Bramley, G.; Power, S. Urban Form and Social Sustainability: The Role of Density and Housing Type. Environ. Plan. B: Plann. Des. 2009, 36, 30-48. [CrossRef]

22. Australia ICOMOS. The Burra Charter. Available online: http://australia.icomos.org/wp-content/uploads/ BURRA_CHARTER.pdf (accessed on 2 March 2019).

23. Bognar, G. The Concept of Quality of Life. Soc. Theory Pract. 2005, 31, 561-580. [CrossRef]

24. Lau, L.K.P.; Lai, W.C.L.; Ho, C.W.D. Quality of Life in a 'High-rise Lawless Slum': A Study of the 'Kowloon Walled City'. Land Use Policy 2018, 76, 157-165. [CrossRef]

25. Ashworth, G.J.; Tunbridge, J.E. The Tourist-Historic City: Retrospect and Prospect of Managing the Heritage City, 1st ed.; Pergamon: New York, NY, USA, 2000; ISBN 0-08-043675-7.

26. Hall, P. Urban and Regional Planning; Routledge: London, UK, 2002.

27. Yung, E.; Chan, E. Is the development control legal framework conducive to a sustainable dense urban development in Hong Kong? Habitat Int. 2004, 28, 409-426.

28. Tweed, C.; Sutherland, M. Built Cultural Heritage and Sustainable Urban Development. Landsc. Urban Plan. 2007, 83, 39-49. [CrossRef]

29. Arnstein, S.R. A Ladder of Citizen Participation. J. Am. Inst. Plan. 1969, 35, 216-224. [CrossRef]

30. Smith, L. The authorized heritage discourse and its use. In Uses of Heritage; Routledge: London, UK; New York, NY, USA, 2006.

31. Tunbridge, J.E. Whose heritage to conserve? Cross-cultural reflections on political dominance and urban heritage conservation. Can. Geogr. 1984, 28, 170-180. [CrossRef]

32. Perring, D. Involving the Public in Archaeological Fieldwork: How Heritage Protection Policies Do Not Always Serve Public Interests. In Sharing Archaeology: Academe, Practice and the Public; Stone, P., Hui, Z., Eds.; Routledge: New York, NY, USA, 2014.

33. Mains, S.P. Fieldwork, heritage and engaging landscape texts. J. Geogr. High. Educ. 2014, 38, 525-545. [CrossRef]

34. Hilton, A. Collaboration in anthropology: The (field)work of grounded practice. Cambio 2018, 8, 113-126. [CrossRef]

35. Allen, A.Y. Fears of Demolition for Historic State Theatre Building in North Point: Heritage Group Calls for Preservation. Available online: https://www.scmp.com/news/hong-kong/education-community/article/ 1919985/fears-demolition-historic-state-theatre-building (accessed on 16 April 2019).

36. Interview with Louis Lor. [This Morning]. Available online: https://www.facebook.com/1109610452404291/ videos/1177984765566859/?hc_ref=SEARCH (accessed on 2 May 2019).

37. Canziani, A. Being and Becoming of Modern heritage: The Challenge of Planned Conservation. In The Challenge of Change: Dealing with the Legacy of the Modern Movement; van den Heuvel, D., Mesman, M., Quist, W., Lemmens, B., Eds.; IOS Press: Amsterdam, The Netherlands, 2008.

38. Prudon, T.H.M. The Preservation of Modern Architecture; Wiley: Hoboken, NJ, USA, 2008.

39. Mualam, N.; Sybblis, M. The functional threshold of modern heritage: Form versus function and the struggle over Tel Aviv's concert hall. Int. J. Herit. Stud. 2016, 22, 145-164. [CrossRef]

40. Mualam, N.; Alterman, R. Architecture is not everything: A multi-faceted conceptual framework for evaluating heritage protection policies and disputes. Int. J. Cult. Policy 2018, 1-21. [CrossRef]

41. Heritage Value Assessment of Former State Theatre. Available online: http://walkin.hk/wp-content/uploads/ 2016/04/Heritage_Value_Assessment_Former_State_Theatre.pdf (accessed on 4 February 2019).

42. Hayes, J. The Hong Kong Region 1850-1911: Institutions and Leadership in Town and Countryside; HKU Press: Hong Kong, China, 2012.

43. Wan Chai Residents Bemoan Loss of Old 'Wedding Card Street'. Available online: http://www.ejinsight.com/ 20151216-old-timers-lament-loss-of-old-wedding-card-street-after-ura-project/ (accessed on 7 March 2019). 
44. Save Our State (unpublished Information Pack). Walk in Hong Kong. 2016.

45. UNESCO. Tangible Cultural Heritage. Available online: http://www.unesco.org/new/en/cairo/culture/ tangible-cultural-heritage/ (accessed on 28 May 2019).

46. Wattchow, B. Landscape and a Sense of place: A Creative Tension. In The Routledge Companion to Landscape Studies; Howard, P., Thomapson, I., Waterton, E., Atha, M., Eds.; Routledge: London, UK, 2013.

47. Completion of the Assessment of 1444 Historic Buildings Announced. Available online: http://www.info.gov. hk/gia/general/200903/19/P200903190254.htm (accessed on 22 December 2018).

48. Rajagopalan, M. Preservation and Modernity: Competing Perspectives, Contested Histories and the Question of Authenticity. In The SAGE Handbook of Architectural Theory; Crysler, C.G., Cairns, S., Heynen, H., Eds.; Sage Publications: Los Angeles, CA, USA, 2012; ISBN 9781446282632.

49. Tomlow, J. Report on the Preservation of the State Theatre in Hong Kong and Its Possible Nomination on a Heritage List. 1952. Available online: https://www.docomomo.com/pdfs/events/heritage/011930_ Jos\%20Tomlow_Report\%20on\%20the\%20preservation\%20of\%20the \%20State $\% 20$ Theatre $\% 20$ in $\% 20$ Hong $\%$ 20Kong\%20and\%20its\%20possible\%20nomination\%20on\%20a\%20Heritage\%20list\%20(1952).pdf (accessed on 10 March 2019).

50. Legislative Council Panel on Development. Progress Report on Heritage Conservation Initiatives. Available online: https://www.legco.gov.hk/yr18-19/english/panels/dev/papers/dev20190122cb1-626-1-e.pdf (accessed on 19 May 2019).

51. Composition of the Expert Panel for the Assessment of 1444 Historic Buildings. Available online: http: //www.aab.gov.hk/form/special_meetings/AAB-SM-A.pdf (accessed on 4 May 2019).

52. Lung, D. Is Heritage for Sale? In Proceedings of the Heritage and Tourism: An International Conference, Hong Kong, China, 13-15 December 1999; Leisure and Culture Services Department: Hong Kong, China, 1999.

53. 2007-2008 Policy Address. Available online: http://www.policyaddress.gov.hk/07-08/eng/p51.html (accessed on 21 January 2018).

54. Egoz, S.; Makhzoumi, J.; Pungetti, G. The Right to Landscape: Contesting Landscape and Human Rights, 1st ed.; Routledge: Farnham, UK, 2011; ISBN 978-1409404446.

55. Schama, S. Landscape and Memory; Vintage: New York, NY, USA, 1996; ISBN 978-0679735120.

56. Antrop, M.; Eetvelde, V.V. Landscape Perspectives: The Holistic Nature of Landscape; Springer: Dordrecht, The Netherlands, 2017.

57. Yung, E.H.K.; Chan, E.H.W. Problem Issues of Public Participation in Built-heritage Conservation: Two Controversial Cases in Hong Kong. Habitat Int. 2011, 35, 457-466. [CrossRef]

58. Meinig, D.W. The Beholding Eye: Ten Versions of the Same Scene. In The Interpretation of Ordinary Landscapes: Geographical Essays; Meinig, D.W., Jackson, J.B., Eds.; Oxford University Press: New York, NY, USA, 1979.

59. Heritage Lottery Fund. Thinking About Community Participation. Available online: http://www. heritagenetwork.dmu.ac.uk/wpcontent/uploads/2013/03/thinking_about_community_participation.pdf (accessed on 31 October 2018).

60. Henderson, J.C. Conserving Hong Kong's Heritage: The Case of Queen's Pier. Int. J. Herit. Stud. 2008, 14, 540-554. [CrossRef]

61. Cheung, E. Hopes Rise for Hong Kong's Historic State Theatre with Developer New World Aiming to Save 'Relevant Part' of Complex. Available online: https://www.scmp.com/news/hong-kong/society/article/ 2169721/hopes-rise-hong-kongs-historic-state-theatre-developer-new (accessed on 31 October 2018).

(C) 2019 by the authors. Licensee MDPI, Basel, Switzerland. This article is an open access article distributed under the terms and conditions of the Creative Commons Attribution (CC BY) license (http://creativecommons.org/licenses/by/4.0/). 